\title{
The Effects of Instructional Scaffolding on High School EFL Students' Making References and Guessing Words' Meanings in Reading Texts: A Case at a High school in Vietnam
}

\author{
Ngoan Chau Thi ${ }^{1}$ and Cong Dan Thai ${ }^{2}$ \\ ${ }^{1}$ Department of English,Hon Dat High School, \\ Kien Giang Province, Vietnam \\ ${ }^{2}$ School of Social Sciences and Humanities, Can Tho University, \\ Can Tho City, Vietnam
}

\begin{abstract}
The study was implemented with 90 Grade 12 students from a rural upper secondary school in Kien Giang Province, Vietnam. The main objectives of this study were to explore the effects of instructional scaffolding on (English as a Foreign Language) EFL high school students' making references and guessing words' meanings in reading texts and to gain an insightful look into high school students' attitudes towards EFL teacher's instructional scaffolding namely questioning and modelling about making references and guessing words' meanings during reading lessons. The study was designed as an experimental study. A mixed method research was employed. Both quantitative and qualitative data were collected by exploiting three significant research instruments in terms of a pretest-posttest, a questionnaire and a semi-structured interview. The findings of the study showed that modeling and questioning greatly affected EFL high school students' English learning. In this particular case of Vietnamese context, modeling and questioning also influenced English vocabulary learning. (1) Both of these techniques increased students' ability to understand and use English vocabulary, (2) these two techniques could be scaffolded and used in learning English vocabulary, and (3) questioning and modeling had a positive impact on high school English learning environment.
\end{abstract}

Key words: instructional scaffolding, modeling, questioning, making references, guessing words' meaning, reading texts, Hon Dat high school

\section{Introduction}

\subsection{Theoretical background}

Among the four language skills, reading is one of the most basic skills that all EFL learners need to acquire when learning English. According to Alfassi (2004), reading is a sophisticated cognitive activity that is crucial for adequate functioning and for gaining information in contemporary society . Grigg and Mann (2008) contended that reading is one of the essential tools contributing to academic success and professional development.

In high school context, a lot of students in senior high school find difficulties when doing reading texts without support from the more capable (Jufri, 2018). Jufri contended that scaffolding model was more effective in helping students to comprehend the reading texts and more helpful in improving students' reading ability than the conventional one. Similarly, Shirmohammadi, M., \& Salehi, M. (2017) concluded scaffolding instruction is effective in improving the reading comprehension of (English for Specific Purposes) ESP learners and scaffolding techniques help ESP learners improve their comprehension more than self-regulated techniques. Shirmohammadi stated that in traditional classes, reading comprehension worked as a tedious task by reading and translating sentence by sentence mechanically. Therefore, the reading parts were always boring and awful for them. In addition, students who receive more scaffolding comprehend the text better than the one receiving less scaffolding (Reynolds \& Goodwin, 2016).

In spite of playing a significant role in reading classes, instructional scaffolding has not been given considerable attention and used as much as needed. 
Lots of EFL learners seem not to receive sufficient scaffolding from their teachers (Khosravi, 2017). It is clear that more research is needed to find out the effects of scaffolding from EFL high school teachers on EFL high school students' reading performance.

\subsection{Contextual background}

Together with the trend of global integration, the need of English learning for international communication is greater than ever before. According to the statistics for English language use (University of Bath, 2018), there are about one quarter of the world population using English. English is also the dominant language in business, science, technology, medicine, international diplomacy and in other disciplines.

In Vietnam, since 2008, the National Foreign Languages Project 2020 (VNFLP 2020) of Vietnam has been launched by the Ministry of Education and Training (MoET) with an ambitious intention to increase Vietnamese people's foreign language proficiency, especially English. It would be expected that by 2020 most of the students finishing high schools, colleges, or universities in Vietnam would be able to use English in their daily communication. Nevertheless, Phuong (2017) stated that the project has not succeeded in meeting lots of its initial targets. There are different reasons leading to the failure of VNFLP 2020. They are English textbook writing, teachers' retraining, disproportionate learning and teaching English demand-supply, teacher low quality, insufficient teaching and learning facilities to name a few (Hoang, 2018).

At the same token, English is one of the three compulsory subjects in the National Graduation Examination and achieving high marks in English contributes to helping students win a place at university. In the National Graduation Examination of English in 2019, reading questions accounted for 3.6 out of 10 marks and in the National Graduation Examination in 2020 , it makes up $34 \%$ overall. This showed the importance of reading skill to high school students. However, many high school students in Viet Nam in general and in Mekong Delta in particular find reading one of the most challenging skills when studying English.

Although a number of studies have contended the effectiveness of scaffolding in reading comprehension (e.g., Al-Eissa \& Al-Bargi, 2017; Chi, 2007; Enyew \& Yigzaw, 2015), questioning and modelling facilitating EFL high school students' making references and guessing words' meaning from reading texts has been paid little attention. Therefore, this study aspired to fill in the gap in which few studies regarding teachers' questioning and modelling in reading lessons are carried out in Vietnam in that field.

\subsection{Research aims}

In this study, its main purposes was, first, to explore the effectiveness of instructional scaffolding on EFL high school students' making references and guessing words' meanings in reading texts, and second, to have an insightful look into EFL high school students' attitudes towards instructional scaffolding namely modelling and questioning at a high school in the Mekong Delta, Vietnam.

\subsection{Research questions}

Along with the mentioned research aims, this study purposefully found out the answers to the following three research questions:

1. To what extent does modelling influence EFL high school students' making references in reading texts? 2. To what extent does questioning influence EFL high school students' guessing words' meanings in reading texts?

3. What are EFL high school students' attitudes towards questioing and modelling?

\section{Review of Literature \\ 2.1 Instructional scaffolding}

Scaffolding theory originates from Lev Vygotsky's sociocultural theory and his concept of the zone of proximal development (ZPD). ZPD distinguishes what a learner can do by himself from what he is unable to do without being scaffolded (Vygotsky, 1978). Instructional scaffolding refers to temporary support provided by the teacher, or more capable peers to help students solve a problem or carry out a task that they cannot accomplish independently. According to Chang, Sung, \& Chen (2002), the scaffolding teaching strategy provides individualized support based on the learner's ZPD. Likewise, Maloch (2002) indicated that instructional scaffolding relates to scaffolding performance of teacher and remarks on some teacher's intervention techniques including direct and indirect elicitations, modeling, highlighting of strategies. Scaffolding means steps to direct a child in focusing on difficult skills and guide him through challenging tasks (Bruner, 1978).

There are different forms of instructional scaffolding, namely question prompts, expert modeling, expert advice, learner guides, resources, tools and so on. By providing EFL learners with sufficient scaffolding, their reading comprehension ability can be improved and gradually they can act independently in identical situations (Poorahmadi, 2009). According to Hammond \& Gibbons (2005), scaffolding can step by step be withdrawn when students can perform their tasks on their own as autonomous readers.

As the review of the foregoing literature reveals that scaffolding refers to teachers' temporary support and can be gradually reduced when students are able to carry out a similar task independently. The final 
aim of scaffolding, therefore, is students' independence in task accomplishment as strategic readers (Reynolds \& Daniel, 2018; van Lier, 1996, 2004).

\subsubsection{Modelling}

From the Oxford dictionary, model is the work of simply describing a system or a process that can be used to explain it. Thesaurus.com defines model as a standard or example for imitation or comparison; a representation to show something's construction or appearance. And also from Webster dictionary, modelling is a general process in which someone serves as a models for others, demonstrating the behavior for the others to imitate. In education, modelling refers to the behavior of both teacher and learners. Susmita Pani (2004) showed that modelling can be an effective pedagogic strategy to stimulate the learners to improve their reading strategies. The author also contended that modelling is process in which teachers and learners are co-participators. It is a technique through which the teacher plays the role of a "superior" reader to make the reading process "visible" and easy for the learners to imitate the steps. And Salisu \& Ransom (2014) expressed that modeling is an instructional strategy in which students learn by observing the way the teacher demonstrates a new concept or approach to learning. This type of instruction can be useful in helping teachers engage students in imitation of particular behaviors that encourage learning.

The aforementioned literature indicates that modelling is useful in teaching reading comprehension. It can be applied among EFL teachers in reading lessons to show and instruct students how to read effectively, which helps enhance students' reading performance.

\subsubsection{Questioning}

From Wikipedia, questioning is a key form of human thought and interpersonal communication. Questioning is the process of forming and wielding that serves to develop answers and insight. Vygotsky (1978) contended that the majority of learning is achieved through the interaction that takes place through communication and collaboration with other people in social settings rather than in isolation. Social interaction is a prerequisite to learning and cognitive development (Vygotsky, 1981). According to Vygotsky, interaction with more capable (teachers, peers, etc.) helps children construct an understanding and solve problems better. Vygotskian theories provide a useful conceptual understanding of how teachers' questioning benefits students. According to Kim (2010), questioning is an effective tool in accelerating linguistic and cognitive development of students in language learning. Similarly, El-Koumy, A. S. A. (2014) concluded that the student teacher reciprocal questioning strategy was effective in developing students' reading comprehension.

\subsection{Reading skill}

Leipzig (2001) contended that reading is a multifaceted process relating to word cognition, comprehension, fluency and motivation. Reading is an instrument to acquire language, to communicate, and to share information and ideas. Likewise, Koda (2007) stated that reading comprehension is a complex process which involves word knowledge, prior knowledge, metacognitive information and reading strategies so that learners can make meaning from the text.

According to Wikipedia (2011), reading is a complicated interaction between the text and the reader shaped by the reader's prior knowledge, experiences, attitude, and cultural and social situation of language community. Reading is a cognitive activity in which the reader takes part in a conversation with the author through the text. Pressley (2000) and Brisch (2011; cited in Abbas, et al., 2016) claimed that reading comprehension is the competence to grasp meaning from what learners read. The researchers also emphasized that it is a complex process because in order to make the meaning from the text, learners need to gain different reading skills like word recognition, lexical knowledge, fluency, the previous knowledge and the like. Likewise, Woolley (2011, cited in Nouf, 2018) stated that reading comprehension requires learners to get a solid cornerstone from fluently decoding words and statements to constructing insights into the whole passage. He also added that reading comprehension is a complicated process that needs an effective collaboration between the learners' background knowledge of the context, the aim of the reading material and the level of vocabulary and language to gain meaning from the text.

The research aimed to study the effects of instructional scaffolding on EFL high school students' making references and guessing words' meaning in reading texts in a high school in the Mekong Delta, Vietnam. There are several reasons why making references and guessing words' meaning were among the reading techniques chosen in the current study. Firstly, in the National Graduation Examination in recent years, the two kinds of questions, making references and guessing words' meaning, make up the highest portion: two in the first reading text and three in the second text. Meanwhile, the questions for other kinds of reading questions make a smaller percentage. For instance, in the National Graduation Examination 2017, and 2018, there were two reading questions involving making references and four reading questions requiring guessing words meaning in reading texts accounting for 40 percent of all reading questions. In the National Graduation Examination in 2019, this 
proportion was 46 percent and in the second sample exam published by The Vietnamese Ministry of Education and Training on April 7th, 2020, these two kinds of reading questions made up $42 \%$. Another reason why making references and guessing words' meaning were selected was that the reading questions in the textbooks mostly checked students' skimming for main ideas and scanning for details. These led to an inadequate practice of the two techniques making inferences and guessing words' meaning. In current textbooks used in high schools in Vietnam such as Tieng Anh 10 (Grade 10), Tieng Anh 11 (Grade 11), Tieng Anh 12 (Grade 12) - a 7- year program and a 10- year program), there are too few reading questions relating to making references. Moreover, reading questions requiring guessing meaning in contexts are not similar to ones in national exams in terms of form.

In conclusion, in the present context of EFL reading learning and teaching in Vietnam, making references and guessing words' meaning in reading texts are essential reading sub skills and need closer attention to contribute to improving reading performance among EFL high school students especially in the annual national exam in English.

\subsubsection{Making references}

Certain items of language in English have the property of reference. They do not have meaning themselves, but they refer to something else for their meaning. Making references is one kind of inference in reading which is called coherence inference. According to Van Den Broek, Beker \& Oudega (2015), coherence inference, also referred to as textconnecting or intersentence inference, which helps maintain textual integrity by establishing cohesion between sentences and by adding unstated information, such as causal links. Van Den Broek et al. (2015) stated that the inferences that relate to semantic relations, like referential and causal/logical contribute the most to comprehension a text. Obviously, without making references while reading, integrating information within the text and filling in implicit information is impossible (Currie \& Cain, 2015).

\subsubsection{Guessing words' meaning}

Parry (1991) found that the success rate ranged from $12 \%$ to $33 \%$. These low rates suggested a need for improvement in the lexical guessing skill. Similarly, according to Fraser (1999), the skill of guessing the meanings of unknown words from context plays an essential part in reading and listening, because it is the most frequent and preferred strategy when learners deal with unknown words in context. Nevertheless, successful rate of guessing among EFL learners is not high. Nassaji (2003) stated that the success rate was only $25.6 \%$ $(44.2 \%$ even if partially correct guesses were included).

\subsection{Attitudes}

According to Business Dictionary, attitude is a predisposition or a tendency to respond positively or negatively towards a certain idea, object, person, or situation. Attitude influences an individual's choice of action, and responses to challenges, incentives, and rewards. An attitude is an evaluation of an object of thought. Attitude objects comprise anything a person may hold in mind, ranging from the mundane to the abstract, including things, people, groups, and ideas (Bohner, G., \& Dickel, N.,2011).

\subsection{Previous studies}

2.4.1. The relationship between instructional scaffolding and reading comprehension

Instructional scaffolding boosts EFL learners' independent and self-regulated competence of skills. The primary benefit of instructional scaffolding is it engages the learners because they do not passively listen to information presented instead through teacher prompting they build on prior knowledge and forms new knowledge. Poorahmadi (2009) stated that by providing EFL learners with sufficient scaffolding, their reading comprehension ability can be improved and gradually they can act independently in identical situations.

In reading, timely and effective scaffolds may facilitate a student's reading comprehension. Instructional scaffolding in teaching reading or explicit teaching of reading strategies to increase students' metacognitive awareness of reading strategies may be efficient reading instruction in EFL classroom. Instructional scaffolding in teaching reading boosts EFL learners' independent and selfregulated competence of skills. The primary benefit of instructional scaffolding in teaching reading is it engages the learners because they do not passively listen to information presented instead through teacher prompting they build on prior knowledge and forms new knowledge.

There are a number of researches investigating the influence of instructional scaffolding on EFL learners' reading comprehension. Poorahmadi (2009) proposed that scaffolding strategies such as skimming, scanning, warm-up activities, L1 translation, modeling a desired behavior, lexical/verbal scaffolding, and paraphrasing a complicated section or asking key questions could accelerate students reading comprehension abilities. Scaffolding such as activating background knowledge before reading, generating questions, or engaging students in reading or discussion while reading, and completing assignments after reading or summarizing information, were used. They concluded that implementing scaffolding strategies effectively upgrades students' reading comprehension. Jufri (2018) indicated that scaffolding model was more effective in helping students to comprehend the reading texts and more 
helpful in improving students' reading ability than the conventional one. Similarly, Younus, \& Khan (2017) showed that students taught through strategybased reading instruction gained more significant achievement in reading comprehension than the ones taught through traditional reading instruction.

2.4.2. The relationship between questioning and reading comprehension

The study conducted in England by Mary Parker \& Jane Hurry (2007) suggested that teacher's modelling and questioning are the most dominant strategies used for teaching reading comprehension. And a study carried out in Indonesia by Sunggingwati and Nguyen (2013) to investigate the practice of teacher questioning and teaching reading in secondary schools revealed that the teachers in this study used the questions in the pre-reading stage to introduce students to the topic and enabling students to recall their background knowledge.

Several studies have been conducted to investigate the effects of questioning on reading comprehension. The research carried out in Vietnam high school context by Tran and Phuong (2018) indicated that questioning and semantic map had positive impact on students' reading comprehension.

The above-mentioned literature reveals that questioning enables teachers to communicate purposefully with students. It is considered one of the means which has been commonly used among EFL teachers to improve students' reading performance. In addition, the foregoing studies have focused on the effects of questioning at pre-reading stage on students' reading comprehension. However, little research has been done to investigate teachers' questioning as a scaffolding strategy at while-reading stage in high school settings. The current study therefore fills the gap of how teachers' questioning may facilitate EFL high school students' making references and guessing words' meaning in reading texts.

\subsubsection{The relationship between modelling} and reading comprehension

A number of studies have been done to investigate kinds of scaffolding which can have positive effects on EFL learners' reading comprehension. Dole \& Pearson (1991) contended that reading instruction includes careful scaffolding. Examples, explicit instructions, modeling, and elaboration are used by teachers to provide sufficient scaffolding necessary for students to learn particular strategies. The scaffolding step by step diminishes when students learn to use and apply the strategies on their own and gradually students become independent users of the strategies.

A research carried out in a school for children in London by Mary Parker \& Jane Hurry (2007) indicated that modelling is frequently used in teaching reading comprehension by the teachers in this study. The authors also suggested that teachers model the strategies used by killed comprehenders without making these strategies explicitly. Another study on modeling reading comprehension and reading fluency in English language grade 1 and grade 2 learners was conducted by Yaghoub \& Geva (2012).

Previous studies have shown that modelling in teaching reading for children at elementary level has received a great deal of concern from the researchers. However, little attention has been paid to teacher's modelling as an instructional scaffolding in reading lessons within the Vietnamese high school context of teaching and learning English as a foreign language. This study, therefore, concentrates on this area of interest and this contributes to the literature of scaffolding EFL high school students' reading comprehension through modelling.

$$
\text { 2.4.4. Students' attitudes towards }
$$
instructional scaffolding

Understanding students' self-efficacy can give teachers key insights into the role of scaffolding in the learning process and help teachers structure learning activities more strategically and effectively. Students' attitudes coming into the learning environment may show a differentiated effect for different forms and levels of scaffolding. Belenky and Nokes-Malackh (2013) contended that students who enter a learning situation with low levels of mastery goals are more likely to benefit from low levels of scaffolding compared with students with high levels of mastery goals.

Motivation or positive attitude is an important principle of foreign language learning. However, a number of EFL learners have very little motivation for learning English, particularly for reading English. Attarzadeh (2011) showed that a majority of foreign student's experience insufficiency in reading despite the importance of English reading. They seem not to desire to learn because their intrinsic motivation is limited, which prevents them from reading effectively. According to Karimi \& Jalivand (2014), a lot of EFL students find understanding the information presented in the written form of English texts challenging and time consuming. When they are not motivated, they are unwilling to spend time reading and make little effort to improve reading skill.

The foregoing literature indicated that students' attitude towards teacher's instructional scaffolding play an important role in deciding the effectiveness of reading lessons. This current study aimed to investigate EFL high school students' attitudes towards teacher's instructional scaffolding namely modelling and questioning in reading class.

As a whole, the literature suggests three main findings. First, modelling and questioning have been commonly used by teachers in reading lessons. These instructional scaffolding have been indicated to be effective in improving learners' reading 
comprehension as well as reading performance. Second, students' attitudes towards teacher's scaffolding play an indispensable role in successful reading classes. Third, there has been little research on instructional scaffolding namely modelling and questioning in EFL high school context in Vietnam. This study therefore attempted to fill in the gaps of how teachers' modelling and questioning affect EFL high school students' making references and guessing words' meaning in reading texts at a Vietnamese high school context.

\section{Materials and Methods}

\subsection{Materials}

Both pre-test and post-tests including three reading passages adapted from 3 books by Hanoi National University Publishing House including "Ren Ky Nang Giai De Thi THPT Mon Tieng Anh" by Vi Thi Mai Phương published in 2016, "Forty theree Bo De Tieng Anh" by Cai Ngocc Duy Anh and Nguyen Thi Dieu Phương published in 2016 and "Bai Tap Tieng Anh Lop 12" by Bui Văn Vinh nd Bui Ngoc Mai published in 2019. The texts used for treatment were adapted from reading texts in Tieng Anh 12 -Grade 12 (a 7- year program and a 10- year programs) and from the National Graduation Examinations in 2017, 2018, and 2019 and two sample examinations published by the Vietnamese Ministry of Education and Training in April and May 2020.

\section{2. Methods}

\subsubsection{Research questions}

With the aim to exploring the effectiveness of instructional scaffolding on EFL high school students' making references and guessing words' meanings in reading texts, and having an insightful look into EFL high school students' attitudes towards instructional scaffolding namely modelling and questioning, this study attempted to answer the following three research questions (1)To what extent does modelling influence EFL high school students' making references in reading texts ? (2) To what extent does questioning influence EFL high school students' guessing words' meanings in reading texts ? and (3) What are EFL high school students' attitudes towards questioning and modelling?

\subsubsection{Research design}

The study adopted a mixed methods research approach combining both quantitative and qualitative approach in order to guarantee that the data collected to answer the three research questions are sufficient and reliable. According to Gay, Mills, \& Airasian (2012), mixed methods approach can provide broad and brief understanding on the research objects. Gay, Mills, \& Airasian (2012) stated that quantitative methods are effective in establishing the effects of a particular intervention, while qualitative ones help us understand relationships and find the answers to "how" questions. In this research, quantitative approach would be applied to measure the effects of instructional scaffolding on EFL high school students' making references and guessing words' meanings in reading texts. Additionally, qualitative approach would be utilized to find out students' attitudes towards instructional scaffolding through questionnaires and interviews.

\subsubsection{Participants}

The study involved 90 EFL Grade 12 students aged around 18 years old of 2 classes at a rural high school in Kien Giang province. The participants are studying the piloted English program for Grade 12. All participants are supposed to be at nearly level three of the Vietnamese Foreign Language Competence Framework since they just finished the first semester of the academic year 2019-2020. They are randomly assigned into two experimental groups. In addition, the participants were tested for their reading subskill performance: making references and guessing words' meanings from reading contexts in order to make sure the homogeneity of the participants.

There are a number of reasons why students of Grade 12 of a rural high school in Kien Giang Province, Vietnam, were chosen as the participants of the research. Firstly, in this school, students' performance in English in the National Graduation Examination in recent years has been low. In the National Graduation Examination in 2017 and 2018 only $12 \%$ and $13.92 \%$ of the grade twelve students ccould get from 5 to 9 marks respectively ( school statistics). Secondly, reading has played an essential role in English in the national exam. In the National Graduation Examination in 2018, and 2019, reading questions accounted for $34 \%$ to $36 \%$ of the total marks in national exam respectively. Therefore, Grade 12 students would improve their exam performance significantly if they could successfully complete the reading questions. Thirdly, reading may be the most challenging of the four English language skills because reading ability requires not only reading strategies but also their knowledge of lexical pattern, culture, and structure (Tran and Phuong, 2018) Additionally, the types of reading questions in the piloted textbook Tieng Anh 12 (Grade 12) are rather different from the ones in the National Graduation Examination, which makes the reading questions in the national exam a big challenge to students. All the above reasons proved Grade 12 students to be the appropriate participants for the research.

All 90 students in the two experimental groups answered the questionnaire and eight students (four from the modelling group and four from the 
questioning group) were selected to take part in the interview about their attitudes towards teacher's modelling and questioning after the treatment.

\subsection{Instruments}

So as to answer the three research questions in the current study, four kinds of data for the research were collected from three sources. Firstly, to answer the two first questions, a pre-test and a post-test were designed to identify whether the application of instructional scaffolding influenced EFL high school students' making references and guessing words' meanings in reading texts. The second instruments were a questionnaire and a semi-structured interview to answer the third research question. The questionnaire and the interview were used after the intervention to know the students' attitudes towards instructional scaffolding, namely modelling and questioning.

\section{Results and Discussions}

4.1. The effects of questioning on EFL high school students' making reference and guessing words' meaning in reading texts

4.1.1. Students' making references and guessing words' meaning in reading texts before the intervention

Table 1: Descriptive Statistics of the Pre-test of “Questioning and Modelling” Groups

\begin{tabular}{|c|c|c|c|c|}
\hline & Min & Max & Mean & $\begin{array}{c}\text { Deviati } \\
\text { on }\end{array}$ \\
\hline & .17 & .83 & .4667 & .17262 \\
\hline $\begin{array}{c}\text { Pre-quest- } \\
\text { reference }\end{array}$ & .17 prestive Statistics of pre-test \\
\hline $\begin{array}{c}\text { Pre-quest- } \\
\text { guess }\end{array}$ & .17 & .67 & .3519 & .15168 \\
\hline $\begin{array}{c}\text { Pre-quest- } \\
\text { total }\end{array}$ & .17 & .67 & .4074 & .10984 \\
\hline $\begin{array}{c}\text { Pre-model- } \\
\text { reference }\end{array}$ & .00 & .83 & .4519 & .21208 \\
\hline $\begin{array}{c}\text { Pre-model- } \\
\text { guess }\end{array}$ & .17 & .83 & .3815 & .16523 \\
\hline $\begin{array}{c}\text { Pre-model- } \\
\text { total }\end{array}$ & .17 & .75 & .4167 & .12934 \\
\hline
\end{tabular}

As can be seen from the data presented in the above table, the lowest scores of participants of questioning experimental groups on both making references and guessing words'meaning in reading texts were 1.7. The highest score of the group in making references $(\mathrm{Max}=8.3)$ was higher than that in guessing words' meanings (Max= 6.7). In addition, the lowest scores of participants of modelling experimental groups on making references and guessing words'meaning in reading texts were 0 $(\mathrm{Min}=0.0)$ and $1.7(\mathrm{Min}=1.7)$ respectively. Meanwhile, the highest score of the group in making references and that in guessing words' meanings was alike $(\operatorname{Max}=8.3)$.

4.1.2. Students' making references and guessing words' meaning in reading texts after the intervention

The data of the following table (Table 2) showed that the lowest score of participants of questioning experimental groups on making references (Min= 0.00 ) was slightly lower than that on guessing words 'meaning in reading texts ( $\mathrm{Min}=0.17)$. Otherwise, the highest score of the group in making references was a little higher $(\mathrm{Max}=1.0)$ than that on guessing words' meaning $(\mathrm{Max}=0.83)$. Additionally, the lowest scores of participants of modelling experimental groups on making references and guessing words 'meaning in reading texts were 0.25 $(\mathrm{Min}=0.25)$ and $0.17(\mathrm{Min}=0.17)$ respectively. Meanwhile, the highest score of the group in making references $(\mathrm{Max}=0.83)$ was slightly smaller than that in guessing words' meanings $(\operatorname{Max}=1.0)$.

Table 2: Descriptive Statistics of the Post-test of “Questioning and Modelling” Groups

\begin{tabular}{|l|r|r|r|r|}
\hline \multicolumn{5}{|c|}{ Descriptive Statistics of post-test } \\
\hline & Min & Max & Mean & $\begin{array}{c}\text { Std. } \\
\text { Deviation }\end{array}$ \\
\hline $\begin{array}{l}\text { Post- } \\
\text { quest- } \\
\text { reference }\end{array}$ & 0 & 1 & 0.5778 & 0.27201 \\
\hline $\begin{array}{l}\text { Post- } \\
\text { quest- } \\
\text { guess }\end{array}$ & 0.17 & 0.83 & 0.4519 & 0.19663 \\
\hline $\begin{array}{l}\text { Pre-quest- } \\
\text { total }\end{array}$ & 0.33 & 0.92 & 0.5148 & 0.14574 \\
\hline $\begin{array}{l}\text { Post- } \\
\text { model- } \\
\text { reference }\end{array}$ & 0.25 & 0.83 & 0.4759 & 0.13369 \\
\hline $\begin{array}{l}\text { Post- } \\
\text { model- } \\
\text { guess }\end{array}$ & 0.17 & 1 & 0.5667 & 0.22019 \\
\hline $\begin{array}{l}\text { Post- } \\
\text { model- } \\
\text { total }\end{array}$ & 0 & 0.83 & 0.3852 & 0.20968 \\
\hline
\end{tabular}

4.3. A comparison between the effects of modelling and questioning on EFL high school students' making references and guessing words' meanings

The data presented in Table 3 below revealed that all indicators of post-test is higher than pre-test. In 
which the sharp increase lay in modeling and questioning of guessing meaning of the word. This showed that students 'guessing the words' meaning was heavily influenced by modeling and questioning.

Table 3: Descriptive Statistics of the Pre-test and Post-test of "Questioning and Modelling" Groups

\begin{tabular}{|l|l|c|c|}
\hline \multicolumn{4}{|c|}{ Paired Samples Statistics } \\
\hline \multirow{2}{*}{} & $\begin{array}{l}\text { Mean } \\
\text { Pair1 }\end{array}$ & $\begin{array}{c}\text { Std. } \\
\text { Deviation }\end{array}$ \\
\cline { 2 - 4 } & $\begin{array}{l}\text { Postmodel } \\
\text { reference }\end{array}$ & 0.4519 & 0.21208 \\
\hline \multirow{2}{*}{ Pair2 } & Premodel guess & 0.3815 & 0.16523 \\
\cline { 2 - 4 } & Postmodel guess & 0.5667 & 0.22019 \\
\hline \multirow{3}{*}{ Pair1 } & Prequestreference & 0.4667 & 0.17262 \\
\cline { 2 - 4 } & $\begin{array}{l}\text { Postquest } \\
\text { reference }\end{array}$ & 0.5778 & 0.27201 \\
\hline \multirow{2}{*}{ Pair2 } & Prequest guess & 0.3519 & 0.15168 \\
\cline { 2 - 4 } & Postquest guess & 0.4519 & 0.19663 \\
\hline
\end{tabular}

Table 4: Pair Sample Test of the Post-test of “Questioning “and “Modelling” Groups

\begin{tabular}{|l|l|r|r|}
\hline \multicolumn{4}{|c|}{ Paired Samples Statistics } \\
\hline \multicolumn{2}{|c|}{} & Mean & $\begin{array}{c}\text { Std. } \\
\text { Deviation }\end{array}$ \\
\hline \multirow{2}{*}{ Pair 1 } & Postquestreference & 0.5778 & 0.27201 \\
\cline { 2 - 4 } & Postmodelreference & 0.4759 & 0.13369 \\
\hline \multirow{2}{*}{ Pair 2 } & Postquestguess & 0.4519 & 0.19663 \\
\cline { 2 - 4 } & Postmodelguess & 0.5667 & 0.22019 \\
\hline
\end{tabular}

On the other hand, Table 4 above showed that questioning and modeling did not have an effect on referencing and guessing students' meaning of the words, in which the questioning method most strongly affected students 'references of the words' meaning.

\subsection{Students' attitudes towards modelling and questioning}

Table 5. Key to understanding the averages (Oxford, 1990)

\begin{tabular}{|l|l|}
\hline Levels & Range \\
\hline Very high & 4.5 to 5.0 \\
\hline High & 3.6 to 4.4 \\
\hline Medium & 2.5 to 3.5 \\
\hline Low & 1.0 to 2.4 \\
\hline
\end{tabular}

Table 6: Descriptive Statistics of students, attitudes towards modelling and questioning

\begin{tabular}{|c|c|c|c|}
\hline \multicolumn{4}{|c|}{ Descriptive Statistics } \\
\hline & Minimum & Maximum & Mean \\
\hline $\begin{array}{c}\text { Model- } \\
\text { interest }\end{array}$ & 2.8 & 4.2 & $\begin{array}{c}3.564 \\
4\end{array}$ \\
\hline $\begin{array}{c}\text { Model- } \\
\text { benefit }\end{array}$ & 3 & 4.33 & $\begin{array}{c}3.614 \\
8\end{array}$ \\
\hline $\begin{array}{c}\text { Model- } \\
\text { feasibility }\end{array}$ & 2.33 & 4 & $\begin{array}{c}3.274 \\
1\end{array}$ \\
\hline $\begin{array}{c}\text { Model- } \\
\text { attitude }\end{array}$ & 3 & 3.94 & $\begin{array}{c}3.539 \\
9\end{array}$ \\
\hline $\begin{array}{c}\text { Quest- } \\
\text { interest }\end{array}$ & 2.4 & 4.4 & $\begin{array}{c}3.457 \\
8\end{array}$ \\
\hline $\begin{array}{c}\text { Quest- } \\
\text { benefits }\end{array}$ & 2.33 & 4.67 & $\begin{array}{c}3.498 \\
8\end{array}$ \\
\hline $\begin{array}{c}\text { Quest- } \\
\text { feasibility }\end{array}$ & 2.33 & 4 & 3.237 \\
\hline $\begin{array}{c}\text { Quest- } \\
\text { attitude }\end{array}$ & 2.71 & 4 & 3.440 \\
\hline
\end{tabular}

As shown in Table 6 above, the overall index of students' attitudes about questioning and modeling was average. This showed that students were not worth the high efficiency of the two methods and did not have strong interest in these two methods.

However, in each specific aspect, students had different perceptions. Regarding their interest, students preferred to study with modeling rather than questioning. In particular, students rated the feasibility of these two methods at lower level when all 45 students participated in the assessment of the below-average feasibility level. However, modeling was more beneficial in helping students learn vocabulary when it was assessed at a high level, while questioning was just average.

This was also confirmed by the answers of eight students participating in the interview (Table 7). They all confirmed that these two methods were necessary in learning English because it brought some advantages. Participant 1 said, "It is helpful. Previously there was no tutorial, I do not know how to start but after being instructed, I can do most of the exercises". And Participant 3 agreed, "Yes, it helps a lot. These make me find more accurate answers, increase the probability of the correct answers". The participants also admitted to linking English learning strategies with these two methods because it helped them improve their ability of using English. Participant 5 reported, "It will be easier to do and help to suggest more, create a ready outline to help better work. There is more progress than no one has instructed." Participant 8 claimed, "Yes, it helps me understand and visualize questions better". In general, the EFL interviewees agreed that both 
modelling and questioning techniques from their classroom teachers helped them to do well on the tests with making references and guessing words' meanings in reading texts.

Table 7 : Interview questions

\begin{tabular}{|c|c|}
\hline Modelling & Questioning \\
\hline $\begin{array}{l}\text { 1. Have you ever been } \\
\text { modelled on making } \\
\text { references and guessing } \\
\text { words 'meaning in reading } \\
\text { texts before? }\end{array}$ & $\begin{array}{l}\text { 1. Have you ever been } \\
\text { questioned on making } \\
\text { references and guessing } \\
\text { words'meaning in reading } \\
\text { texts before? }\end{array}$ \\
\hline $\begin{array}{l}\text { 2. Do you think that EFL } \\
\text { teacher's modelling on } \\
\text { making references and } \\
\text { guessing words 'meaning in } \\
\text { reading texts is necessary? } \\
\text { Why? } \\
\text { 3. Do you make any } \\
\text { progress on making } \\
\text { references and guessing } \\
\text { words 'meaning in reading } \\
\text { texts after being modelled } \\
\text { by your EFL teacher? } \\
\text { How? }\end{array}$ & $\begin{array}{l}\text { 2. Do you think that EFL } \\
\text { teacher's questioning on } \\
\text { making references and } \\
\text { guessing words'meaning in } \\
\text { reading texts is necessary? } \\
\text { Why? } \\
\text { 3. Do you make any } \\
\text { progress on making } \\
\text { references and guessing } \\
\text { words'meaning in reading } \\
\text { texts after being questioned } \\
\text { by your EFL teacher? } \\
\text { How? }\end{array}$ \\
\hline $\begin{array}{l}\text { 4. Do you love being } \\
\text { modelled by your EFL } \\
\text { teacher on making } \\
\text { references and guessing } \\
\text { words 'meaning in texts? } \\
\text { Why? }\end{array}$ & $\begin{array}{l}\text { 4. Do you love being } \\
\text { questioned by your EFL } \\
\text { teacher on making } \\
\text { references and guessing } \\
\text { words'meaning in reading } \\
\text { texts? Why? }\end{array}$ \\
\hline $\begin{array}{l}\text { 5. What do you expect your } \\
\text { EFL teacher to do to help } \\
\text { you improve your reading } \\
\text { skill? }\end{array}$ & $\begin{array}{l}\text { 5. What do you expect your } \\
\text { EFL teacher to do to help } \\
\text { you improve your reading } \\
\text { skill? }\end{array}$ \\
\hline
\end{tabular}

\subsection{Discussions}

4.5.1. The effects of guessing meaning from context and semantic mapping on EFL students' reading comprehension

Modeling and questioning greatly affects students' English learning. In this particular case, guessing the meaning of the words from different contexts. This is similar to the results of Fraser (1999), Nassaji (2003) and Parry (1991) who assert that guessing the words' meaning from contexts plays a significant role in learning English vocabulary of high school students who have limited capacity. The data and results also show that in the context of Vietnam, modeling and questioning also affects English vocabulary learning. Both of these techniques increase students' ability to understand and use English vocabulary. This result is not different from other studies such as Vygotsky, 1981), Kim (2010), El-Koumy, (2014), Susmita Pani (2004), and Salisu \& Ransom (2014). The benefits of these two techniques can be summarized as follows: (1) They stimulate or scaffold students in learning English vocabulary, (2) the interaction that takes place through communication and collaboration are effective in helping learners remember vocabulary and (3) they accelerate linguistic and develop students' cognition in language learning.

4.5.2. EFL high school students' attitudes towards the implementation of guessing meaning from context and semantic mapping in reading class

In terms of students' perceptions of using modeling and questioning in English class, the participants in this study are also the same with Dole \& Pearson (1991), Mary Parker \& Jane Hurry (2007) when they claimed that these two techniques can scaffold and use in learning English vocabulary. Similarly, these two techniques have similar results with Tran and Phuong (2018) when the results index indicates that they had positive impact in high school English learning environment.

\section{Conclusions}

\subsection{Conclusion}

The study was carried out in order to investigate the effects of the effects of modelling and questioning on EFL high school students' making references and guessing words' meaning in reading texts as well as the attitudes of the participants towards teacher's modelling and questioning at a high school context. The study adopted a mixed methods research approach combining both quantitative and qualitative approach attempting to answer the three research questions: (1) To what extent does modelling influence EFL high school students' making references in reading texts ?; (2) To what extent does questioning influence EFL high school students' guessing words' meanings in reading texts? (3) What are EFL high school students' attitudes towards questioing and modelling? The above findings and detailed explanations were proved successfully.

\subsection{Pedagogical implications}

The study has a number of implications for reading instruction in high schools in Mekong Delta, Vietnam, as well as contexts which have the same characteristics as the research setting. Firstly, strategy-based reading instruction may be more effective when being combined with metacognitive scaffolding and symmetrical scaffolding. Secondly, for syllabus designers, it is essential to include explanation and exercises for developing metacognitive awareness of reading strategies in textbooks. Thirdly, there should be more training workshops, seminars, conferences and other events on strategy-based reading instruction for high school EFL teachers in Mekong Delta. Fourthly, for high school EFL teachers, to be effective scaffolders, they need to be sensitive to individual difficulties and decide if help should be given, how much help 
should be given, the timing of giving the help, and the goal of the instruction. When scaffolding, it is necessary for teachers to bear their learners and their always changing ZPD in mind. Scaffolding should be removed gradually until students can perform the task independently.

\subsection{Suggestions for future research}

For future research on this topic, a more thorough study can be designed to investigate other complexity and challenges of $\mathrm{L} 2$ reading such as word recognition, reading fluency.... Moreover, as the target population in the current study was the high school students in rural areas of Mekong Delta, so future studies on the topic could be conducted with the university and college students or high school students in urban areas with higher language proficiency. Finally, as the current study investigated the effect of strategy-based reading instruction on EFL learners' reading comprehension, future research can be more comprehensive by incorporating motivation, reading attitude, socioeconomic background, and gender.

In short, the study has explored the potential effect of strategy-based reading instruction incorporating both metacognitive and symmetrical scaffolding on EFL learners' reading comprehension at high school level, and found it to be a more effective method for reading instruction than conventional ones. It is expected that the findings of this study can be useful in enhancing English reading proficiency and skills of high school students in Mekong Delta, Vietnam.

\section{Acknowledgments}

As to get this study done, the researchers would, first and foremost, like to express their sincere thanks to lecturers at Can Tho University (CTU) Vietnam, especially those at School of Foreign Languages (SFL) and at School of Social Sciences \&Humanities (SSSH), CTU, and from College of Foreign Languages-Hue University, Vietnam for their teaching and supervisions towards "Principles and Methods in English Language Education Program" at SFL, CTU, Vietnam and the researchers' MA classmates of Cohort 25 (2018-2020). Secondly, their great thanks would come to high school EFL teachers and students from Hon Dat high school, Kien Giang Province, Vietnam for their kind co operations to the research through classroom experimental study, the questionnaire, and interviews. And last but not least, their respectful thanks would go to IJASRM journal board for this paper to be published to the public, especially those interested in teaching and learning English in Vietnamese educational levels, particularly in high school one entering the regionally and globally educational contexts.

\section{References}

[1] Abbas, P.G., Narjes, B.S. (2016). A Study of Factors Affecting EFL Learners' Reading Comprehension Skill and the Strategies for Improvement. International Journal of English Linguistic, 6(5), p. 180-187.

[2] Alfassi, M. (2004). Reading to learn: Effects of combined strategy instruction on high school students. Journal of Educational Research, 97(4), 171-184.

[3] Attarzadeh, M. (2011). The effect of scaffolding on reading comprehension of various text modes on Iranian EFL learners with different proficiency levels. Social Sciences, 2, 1-28.

[4] Baker, W. \& Boonkit, K. (2004). Learning Strategies in Reading and Writing: EAP Contexts. RELC Journal, 35(3): 299-328.

[5] Belenky, D. M., \& Nokes-Malach, T. J. (2013). Mastery-approach goals and knowledge transfer: An investigation into the effects of task structure and framing instructions. Learning and Individual Differences, 25, 21-34.

[6] Bohner, G., \& Dickel, N. (2011). Attitudes and Attitude Change. Annual Review of Psychology, 62(1), 391-417.

https://doi.org/10.1146/annurev.psych.121208.131609

[7] Bruner, J. (1978). The role of dialogue in language acquisition. In A. Sinclair, R. Jarvella, \& W. Levelt (Eds.), The child's Conception of Language (pp.241256). New York: SpringerVerlag.

[8] Carrell, P.L. (1989). Metacognitive awareness and second language reading. Modern Language Journal, $73,120-133$.

[9] Carol, R. (2002). Mindful reading: strategy training that facilitates transfer. Journal of Adolescent \& Adult Literacy, Vol. 45(6), 498-513.

[10] Chang, K., Chen, I., \& Sung, Y. (2002). The effect of concept mapping to enhance text comprehension and summarization. The Journal of Experimental Education 71(1), 5-23.

[11] Cohen, A. D. (1990). Language learning: Insights for learners, teachers, \& researchers. NY: Newbury House Publishers.

[12] Currie, N. K. \& Cain, K. (2015). Children's inference generation: The role of vocabulary and working memory. Journal of Experimental Child Psychology, 137, 57-75.

[13] Dole, J. A., Duffy, G. G., Roehler, L. R., \& Pearson, P. D. (1991). Moving From the Old to the New: Research on Reading Comprehension Instruction. Review of Educational Research, 61(2), 239-264. https://doi.org/10.3102/00346543061002239

[14] El-Koumy, A. S. A. (2014). Effects of Three Questioning Strategies on EFL Reading Comprehension. SSRN Electronic Journal. https://doi.org/10.2139/ssrn.2364867

[15] Emma Phillips (2013) A case study of questioning for reading comprehension during guided reading, Education 3-13, 41:1, 110120, DOI: $10.1080 / 03004279.2012 .710106$

[16] Fordham, N. W. (2006). Crafting questions that address comprehension strategies in content reading. Journal of Adolescent \& Adult Literacy, 49(5), 390396. 
[17] EACEA/Eurydice (2011). Teaching Reading in Europe: Contexts, Policies and Practices. Brussels: Eurydice.

[18] Fraser, C.A.(1999).Lexical processing strategy use and vocabulary learning through reading. Studies in Second Language Acquisition, 21(2), 225-241. https://doi.org/10.1017/S0272263199002041

[19] Gay, L. R., Mills, G. E., \& Airasian, P. (2012). Educational Research: Competencies for Analysis and Applications. (10th Ed.). New Jersey: Pearson Education.

[20] Grigg, N. \& Man, R. (2008). "Promoting excellence: An international study into creating awareness of business excellency models". The TQM Journal, 20(3), 233-248

[21] Hoang, V. V. (2018). The Current Situation and the Teaching of English in Vietnam. Retrieved on March 1, 2019 from https://www.researchgate.net/publication/326718789_ The_Curent_Situation_and the_Teaching_of_English in_Vietnam

[22] Karimi, L. \& Jalivand, M. (2014). The Effect of Peer and Teacher Scaffolding on the Reading Comprehension of EFL Learners in Asymmetrical and Symmetrical Groups. The Journal of Teaching Language Skill (JTLS), 5(4), 1-17.

[23] Koda, K. (2007). Reading Language Learning: CrossLinguistic Constraints on Second Language Reading Development. Language Learning, 57(1), p. 1-44.

[24] Leipzig, D. H. (2001, January). What is Reading? Retrieved 8 23, 2011, from Reading Rockets: http://www.readingrockets.org/article/352/

[25] Jufri. (2018). The Effectiveness of Scaffolding Model in Teaching Reading at Senior High Schools in Padang City. Advances in Social Science, Education and Humanities Research, 301, p. 413-420

[26] Khosravi, S. (2017). Symmetrical and Asymmetrical Scaffolding in English Reading Comprehension of Iranian EFL Learners. European Journal of English Language Teaching, 0 .

[27] Klingner, J. K., Vaughn, S., \& Boardman, A. (2007). Teaching reading comprehension to students with learning difficulties. New York: Guilford Press.

[28] Leipzig, D. H. (January, 2001). What is reading? WETA.

[29] Mary Parker \& Jane Hurry (2007) Teachers' use of questioning and modelling comprehension skills in primary classrooms, Educational Review, 59:3, 299314, DOI: $10.1080 / 00131910701427298$

[30] McNamara, C. (1999). General Guidelines for Conducting Interviews. Minnesota.

[31] Nassaji, H.(2003).L2 vocabulary learning from context: strategies, knowledge sources, and their relationship with success in L2 lexical inferencing.TESOL Quarterly, 37(4), 645-670. https://doi.org/10.2307/3588216

[32] Parry, K.(1991).Building a vocabulary through academic reading.TESOL Quarterly, 25(4), 629653.https://doi.org/10.2307/3587080

[33] Phuong, H. Y. (2017). Improving English language teaching in Vietnam: Voices from university teachers and students. The People of Vietnam: Their Voices and Lived Experiences. Hauppauge, NY: Nova Science publishers, Inc.
[34] Poorahmadi, M. (2009). The Effect of Employing Scaffolding Strategies and Classroom Tasks in Teaching Reading Comprehension. Teaching English as a Foreign Language and Literature, 1(3), 87-106.

[35] Reynolds, D., \& Goodwin, A. (2016). Supporting Students Reading Complex Texts. AERA Open, 2(4), 1-16. https://doi.org/10.1177/2332858416680353

[36] Reynolds, D., \& Daniel, S. (2018). Toward contingency in scaffolding reading comprehension: Next steps for research. Reading Research Quarterly, 53(3), 363-373.

[37] Sapsford, R. \& Jupp, V. (2006). Data collection and Analysis. ( $2^{\text {nd }} E d$.). London: Sage Publication.

[38] Slataci, R. \& Akyel, A. (2002). Possible effects of strategy instruction on $\mathrm{L} 1$ and $\mathrm{L} 2$ reading. Reading in a Foreign Language, 14(1), 1-16.

[39] Sunggingwati, D., \& Nguyen, H. T. M. (2013). Teachers' questioning in reading lessons: A case study in Indonesia. Electronic Journal of Foreign Language Teaching, 10(1), 80-95.

[40] Susmita Pani, Reading strategy instruction through mental modelling, ELT Journal, Volume 58, Issue 4, October 2004, Pages 355362, https://doi.org/10.1093/elt/58.4.355:

[41] Tran, T.T.T., \& Phuong, Y. H (2018). The impact of questioning and semantic map in pre-reading stage on students' reading comprehension: A comparative study. European Journal of Education Studies, 4(6), 279-294.

[42] University of Bath (2018). Teaching English and teaching through English: Two global trends. Retrieved on March 9, 2019 from https://www.studyinternational.com/news/teachingenglish-and-teaching-through-english-two-globaltrends/

[43] Van Den Broek, P., Beker, K. \& Oudega, M. (2015). Inference generation in text comprehension: Automatic and strategic processes in the construction of mental representation. In E.J. O'Brien, A.E. Cook \& R.F. Lorch (Eds.), Inferences during reading (pp. 94-121). Cambridge, UK: Cambridge University Press.

[44] Van Lier, L. (1996). Interaction in the language curriculum: Awareness, autonomy and authenticity. London: Longman.

[45] Van Lier, L. (2004). The ecology and semiotics of language learning. Dordrecht: Kluwer Academic.

[46] Vygotsky, L. S. (1978). Mind in society: The development of higher psychological processes. Cambridge, M.A.: Harvard University Press.

[47] Vygotsky, L. S. (1981). The genesis of higher mental functions. In J. V. Wertsch (Ed.), The Concept of Activity in Soviet Psychology (pp. 144-188). Armonk, N.Y.: M. E. Sharpe

[48] Vu, M.P. (2016). Rèn Luyện Kỹ năng giải Đề Thi THPT môn Tiếng Anh, Ha Noi National University

[49] Walker, J. B. (2000). Diagnostic teaching of reading: Techniques for instruction and assessment (4th ed.). OH: Merril.

[50] Wikipedia. (2011, 8 15). Reading (process). Retrieved 8 23, 2011, from Wikipedia: http://en.wikipedia.org/wiki/Reading_\%28process\%2 9

[51] Zare, P. \& Nooreen, N. ( 2011). The Relationship Between Language Learning Strategy Use and 
Reading Comprehension Achievement Among Iranian Undergraduate EFL Learners. World Applied Sciences Journal. 13(8): 1870-1877.

[52] Salisu, A., \& Ransom, E. N. (2014). The Role of Modeling towards Impacting Quality Education. International Letters of Social and Humanistic Sciences, 32

54-61. https://doi.org/10.18052/www.scipress.com/ilshs.32.5

\section{ISSN 2455-6378}

[53] Shirmohammadi, M., \& Salehi, M. (2017). Comparative Effect of Scaffolding Instruction and Self-Regulated Learning on ESP Learners' Reading Comprehension. International Journal of English Language \& Translation Studies, 5(4), 203-213.

[54] Yaghoub Zadeh, Z., Farnia, F. \& Geva, E. Toward modeling reading comprehension and reading fluency in English language learners. Read Writ 25, 163-187 (2012). https://doi.org/10.1007/s11145-010-9252-0 